\title{
SYNTHESIS AND ANTIMICROBIAL EVALUATION OF SOME NEW ASYMMETRICALLY SUBSTITUTED 4-ARYL- 2,6-DI(COUMARINYL) PYRIDINES
}

\author{
YOGITA L. CHOVATIYA, KAUSHIK N. KUNDALIYA, RAKESH R. GIRI AND \\ DINKER I. BRAHMBHATT*
}

Department of Chemistry, Sardar Patel University, Vallabh Vidyanagar 388120, Gujarat, India

\begin{abstract}
In the present work the synthesis of various 4-aryl-2-(coumarin-3-yl)-6-(4-methyl-3-phenyl coumarin-6-yl)pyridines (6a-i) and 4-aryl-2-(coumarin-3-yl)6-(4-methyl-7-methoxy coumarin-8-yl)pyridines (7a-i) have been carried out by reacting 1-[2(H)-1-benzopyran-3-yl]-3-aryl-prop-2-en-1-ones (coumarinoyl chalcones) (3a-f) with appropriate coumarinoyl methyl pyridinium bromide salt $\mathbf{4}$ and $\mathbf{5}$ respectively. The target compounds were characterized by the IR, ${ }^{1} \mathrm{H}-\mathrm{NMR},{ }^{13} \mathrm{C}$-APT and mass spectral analysis. Preliminary examination of target compounds as antimicrobial agents has been carried out using Broth dilution method.
\end{abstract}

Keywords: Dicoumarinyl pyridines, Krohnke's reaction, antimicrobial activity, Broth dilution method

\section{INTRODUCTION}

Over past few decades, resistance to antimicrobial agents among bacterial and fungal pathogens represent major global health problem in terms of morbidity and mortality'. Infections caused by resistant microorganisms often fail to respond to the standard treatment, resulting in prolonged illness, higher health care expenditures, and a greater risk of death. Thus, to conquer such multidrug resistant pathogens is challenging task in present era. Therefore, there is crucial need to discover and develop effective antimicrobial agents with novel mechanisms of action and enhanced activity.

At present, coumarin represents one of the classes of versatile biodynamic agents, which are plentiful in plant kingdom and present as basic frame in potent pharmaceutical compounds. The promising biological profile offered by coumarin and its derivatives attributed to enormous diversity in substitution patterns on core scaffold. Coumarins play pivotal role in drug discovery exhibiting various therapeutic actions such as anticoagulant ${ }^{2}$, antitumor ${ }^{3}$, antiinflammatory ${ }^{4}$, hypolipidaemic ${ }^{5}$, vasorelaxant ${ }^{6}$, CNS depressant ${ }^{7}$, antioxidant ${ }^{8}$, anti- $\mathrm{TB}^{9}$ and antimalarial ${ }^{10}$ activities.

The interesting biological profiles of the coumarins make them adaptable targets in organic synthesis. Therefore, a detailed literature survey concerning the coumarins derivatives was carried out, through which we came across some 3-(2-pyridyl) and 3-(3-pridyl)coumarins which are recognized for their useful bioactivities viz. antifungal ${ }^{11}$, bactericidal ${ }^{12}$, fish toxicity ${ }^{13}$, moth proofing activity ${ }^{13}$ and CNS depressant activity ${ }^{14}$. Encouraged from the significant biological essence of pyridine substituted coumarins, a series of new 3-(2-pyridyl) ${ }^{1520}$, 6-(2-pyridyl $)^{21}$ and 8-(2-pyridyl)coumarins ${ }^{22}$ and their antimicrobial assessment were reported from our laboratory. Additionally, we also reported some new dicoumarinyl substituted pyridine ${ }^{23}$ in which synthesized coumarins adjoined pyridine by $3^{\text {rd }}$ position. Thus two cumarin moieties were having symmetrical linkage with pyridine moiety and the attachment was by $\left(3,3^{\prime}\right)$ positions of coumarins as shown in figure 1 .

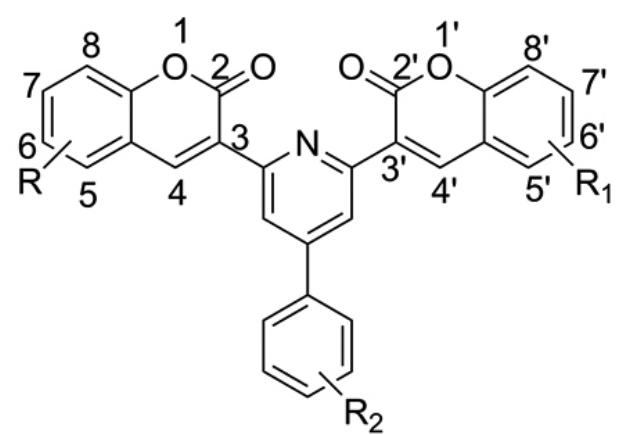

Figure 1: Attachment of two coumarin moieties with pyridine by $\left(3,3^{\prime}\right)$ linkage.

In glance of our previous study here in, we report the synthesis of dicoumarinyl substituted pyridine in which the coumarin moieties are attached with pyridine moiety by different positions i.e by $\left(3,6^{\prime}\right)[\mathrm{A}]$ and $\left(3,8^{\prime}\right)[\mathrm{B}]$ as shown in figure 2 respectively. Additionally, the synthesized compounds were also evaluated for their antimicrobial potential.<smiles></smiles>

$\left(3,6^{\prime}\right) \quad[A]$<smiles>COc1ccc2c(C)cc(=O)oc2c1-c1cc(-c2ccccc2)cc(-c2cc3ccccc3oc2=O)n1</smiles>

$\left(3,8^{\prime}\right) \quad[B]$

Figure 2: Attachment of two coumarin moieties with pyridine by different positions i.e by $\left(3,6^{\prime}\right)[\mathrm{A}]$ and $\left(3,8^{\prime}\right)[\mathrm{B}]$.

\section{RESULTS AND DISCUSSION}

Chemistry

In the present work, various 4-aryl-2-(coumarin-3-yl)-6- (4-methyl3-phenyl coumarin-6-yl)pyridines 6a-i and 4-aryl-2-(coumarin-3-yl)-6(7-methoxy-4-methylcoumarin-8-yl) pyridines 7a-i have been synthesized by the reacting 1-[2(H)-1-benzopyran-3-yl]-3-aryl-prop-2-en-1-ones 3a-f with 4-methyl-3-phenyl-6-coumarinoyl methyl pyridinium bromide salt $\mathbf{4}$ and 7-methoxy-4-methyl-8-coumarinoyl methyl pyridinium bromide salt 5 respectively in the presence of ammonium acetate and acetic acid under Kröhnke's reaction condition ${ }^{24}$ as displayed in scheme 1. 


\begin{tabular}{|c|c|c|c|c|c|c|c|c|c|c|}
\hline Compounds & $\mathbf{R}$ & $\mathbf{R}_{\mathbf{1}}$ & $\mathbf{R}_{\mathbf{2}}$ & $\mathbf{R}_{\mathbf{3}}$ & Compounds & $\mathbf{R}$ & $\mathbf{R}_{\mathbf{1}}$ & $\mathbf{R}_{\mathbf{2}}$ & $\mathbf{R}_{\mathbf{3}}$ \\
\hline $\mathbf{6 a}, \mathbf{7 a}$ & $\mathrm{H}$ & $\mathrm{H}$ & $\mathrm{H}$ & $\mathrm{H}$ & $\mathbf{6 f}, \mathbf{7 f}$ & $\mathrm{OCH}_{3}$ & $\mathrm{H}$ & $\mathrm{H}$ & $\mathrm{OCH}_{3}$ \\
\hline $\mathbf{6 b}, \mathbf{7 b}$ & $\mathrm{H}$ & $\mathrm{H}$ & $\mathrm{H}$ & $\mathrm{CH}_{3}$ & $\mathbf{6 g}, \mathbf{7 g}$ & $\mathrm{H}$ & $\mathrm{Benzo}$ & $\mathrm{H}$ \\
\hline $\mathbf{6 c}, \mathbf{7 c}$ & $\mathrm{H}$ & $\mathrm{H}$ & $\mathrm{H}$ & $\mathrm{OCH}_{3}$ & $\mathbf{6 h}, \mathbf{7 h}$ & $\mathrm{H}$ & $\mathrm{Benzo}$ & $\mathrm{CH}_{3}$ \\
\hline $\mathbf{6 d}, \mathbf{7 d}$ & $\mathrm{OCH}_{3}$ & $\mathrm{H}$ & $\mathrm{H}$ & $\mathrm{H}$ & $\mathbf{6 i}, \mathbf{7 i}$ & $\mathrm{H}$ & $\mathrm{Benzo}$ & $\mathrm{OCH}_{3}$ \\
\hline $\mathbf{6 e}, \mathbf{7} \mathbf{e}$ & $\mathrm{OCH}_{3}$ & $\mathrm{H}$ & $\mathrm{H}$ & $\mathrm{CH}_{3}$ & & & & \\
\hline
\end{tabular}<smiles>[R]c1cc([R])c2oc(=O)c(C(C)=O)cc2c1[R]</smiles>

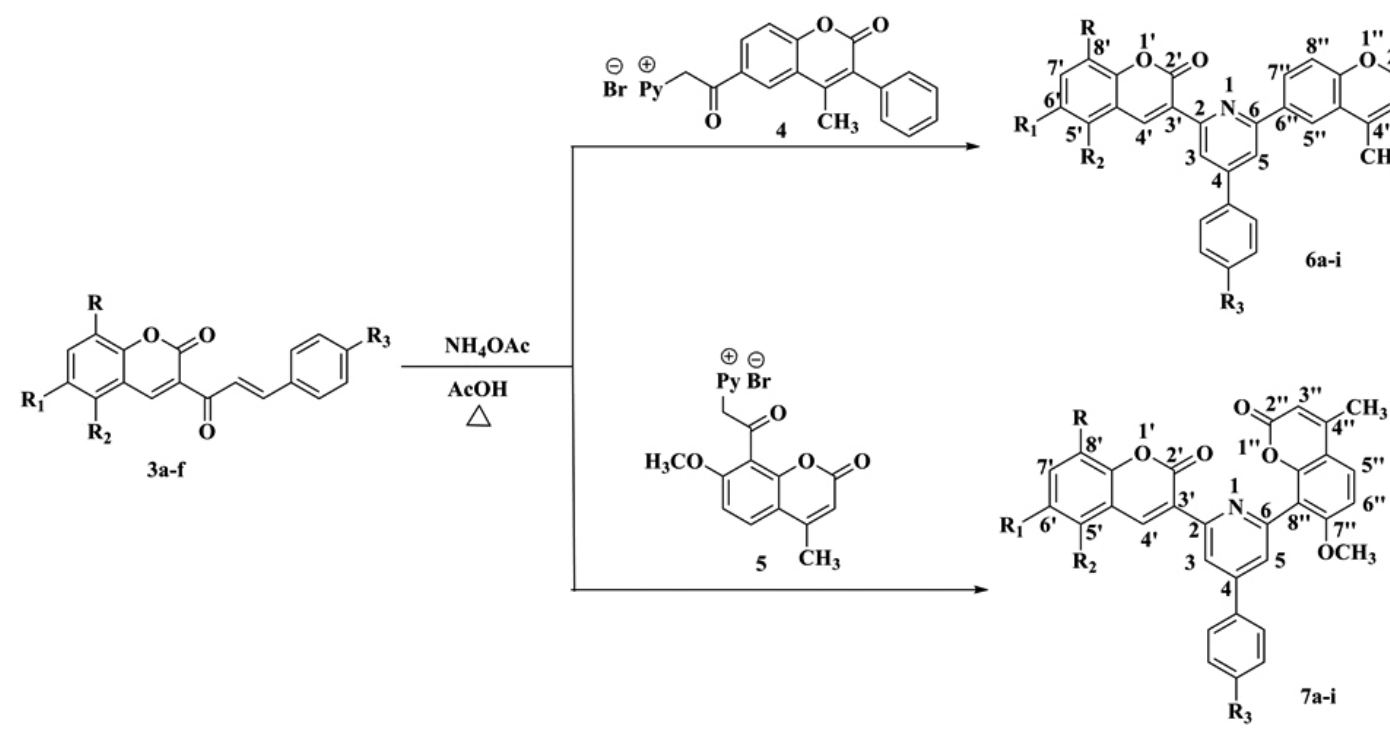

Scheme 1: Synthetic pathway for the preparation of starting precursor 3a-f, target compounds 6a-1 and 7a-i.

The structures of all the synthesized compounds were confirmed on the basis of ${ }^{1} \mathrm{H}-\mathrm{NMR}$; ${ }^{13} \mathrm{C}-\mathrm{APT}$; IR; elemental analysis and representative mass spectral data.

Amongst the compounds $\mathbf{6 a - i}$, the IR spectrum of compound $\mathbf{6 a}$ exhibited the band at 3054 and $2924 \mathrm{~cm}^{-1}$ are due to aliphatic C-H and aromatic C-H stretching vibrations. The characteristic strong and sharp band observed at $1716 \mathrm{~cm}^{-1}$ for carbonyl stretching of $\delta$-lactone ring of coumarin nucleus. The bands observed at 1611 and $1457 \mathrm{~cm}^{-1}$ are due to aromatic $\mathrm{C}=\mathrm{C}$ and $\mathrm{C}=\mathrm{N}$ stretching vibrations. A sharp and intense band observed at $761 \mathrm{~cm}^{-1}$ is due to $\mathrm{C}-\mathrm{H}$ out of plane bending vibrations for mono substituted benzene ring. The ${ }^{1} \mathrm{H}-\mathrm{NMR}$ spectrum of compound $\mathbf{6 a}$ showed a singlet at $2.47 \delta$ integrating for three protons, which is due to methyl group protons. The signal for $\mathrm{C}^{\prime \prime}{ }_{7}-\mathrm{H}$ appeared as doublet of doublet in the downfield region centered at $8.35 \delta(J=$ 8.8 and $1.6 \mathrm{~Hz})$. The $\mathrm{C}^{\prime}{ }_{5}-\mathrm{H}$ appeared as meta coupled doublet at $8.42 \delta(J=1.6$ $\mathrm{Hz}$ ). A poorly resolved meta coupled doublet centered at $8.68 \delta$ corresponds to proton attached to $\mathrm{C}_{3}$ of the pyridine ring. The $\mathrm{C}_{3}-\mathrm{H}$ of pyridine ring appeared in the downfield region due to peri effect of carbonyl group of $\delta$-lactone. The signal for $\mathrm{C}_{4}$ of the coumarin ring appeared in the most downfield region at $8.95 \delta$ is due to peri effect of nitrogen $\mathrm{N}_{1}$. The remaining sixteen aromatic protons appeared as a multiplet between $7.28-7.93 \delta$. The ${ }^{13} \mathrm{C}$-APT spectrum of compound 6a showed signals at $16.80 \delta$ is due to methyl carbon. The signal appeared at 160.33 and $160.76 \delta$ are due to carbonyl carbon of the $\delta$-lactone ring of two coumarin moieties. The signals for thirty non equivalent carbons present in the compound appeared between $116.46 \delta$ to $156.00 \delta$. The mass spectrum of compound 6a showed molecular ion peak at $\mathrm{m} / \mathrm{z} 533.0$ along with other fragments corresponding to molecular formula $\mathrm{C}_{36} \mathrm{H}_{23} \mathrm{NO}_{4}$.

Among the compounds 7a-i, the IR spectrum of compound 7 a showed the band at 3057 and $2924 \mathrm{~cm}^{-1}$ are due to aliphatic C-H and aromatic C-H stretching vibrations respectively. A strong band at $1724 \mathrm{~cm}^{-1}$ due to carbonyl stretching of $\delta$-lactone ring present in coumarin nucleus. The bands observed at 1611 and $1457 \mathrm{~cm}^{-1}$ are due to aromatic $\mathrm{C}=\mathrm{C}$ and $\mathrm{C}=\mathrm{N}$ stretching vibrations respectively. A sharp and intense band observed at $748 \mathrm{~cm}^{-1}$ is due to C-H out of plane bending vibrations for mono substituted benzene ring. The ${ }^{1} \mathrm{H}-\mathrm{NMR}$ spectrum of compound 7a showed a two singlet appeared at 2.69 and $3.90 \delta$ integrating for three protons are of methyl group and methoxyl group respectively. A singlet appeared at $6.21 \delta$ correspond to proton attached to $\mathrm{C}_{3}$ '"-H. A meta coupled doublet observed at $8.59 \delta(J=1.6 \mathrm{~Hz})$ is due to $\mathrm{C}_{3}-\mathrm{H}$ proton of pyridine ring. A singlet appeared at $8.76 \delta$ and integrating for one proton is due to proton attached at $\mathrm{C}_{4}$. The $\mathrm{C}_{4}{ }_{4}$ proton appears in the downfield region due to the peri effect of nitrogen. The remaining twelve aromatic protons appeared as multiplet between 7.79-7.06 $\delta$. The ${ }^{13} \mathrm{C}$-APT spectrum of compound $7 \mathbf{a}$ showed signals at 19.61 and $56.47 \delta$ are due to methyl carbon and methoxyl carbon respectively. The signal appeared at 160.11 and 160.53 $\delta$ can be assigned to carbonyl carbon of the $\delta$-lactone ring of two coumarin moieties. The signals for the other aromatic carbons appeared between 108.33 $\delta$ to $159.18 \delta$. The mass spectrum of compound 7a showed molecular ion peak at $\mathrm{m} / \mathrm{z} 443.0$ along with other fragments corresponding to molecular formula $\mathrm{C}_{31} \mathrm{H}_{21} \mathrm{NO}_{4}$. The analytical data for the other derivatives were discussed in experimental section.

The analytic and spectroscopic data of remaining synthesized compounds are given in the Supplementary Material to this paper.

\section{Evaluation of Antimicrobial activity}

All the synthesized compounds were screened for their in vitro antimicrobial activity by Broth dilution method ${ }^{25}$. All the newly synthesized compounds $\mathbf{6 a}-\mathbf{i}$ and 7a-i exerted significant inhibitory activity against all the employed strains. Upon evaluating antimicrobial activity data in Table I, it was observed that compounds $7 \mathbf{b}$ and $7 \mathbf{h}(\mathrm{MIC}=62.5 \mu \mathrm{g} / \mathrm{ml})$ exhibited superior activity compare to Ampicillin $(\mathrm{MIC}=250 \mu \mathrm{g} / \mathrm{ml}$ ) against gram positive bacteria $S$. aureus, while compounds $6 \mathrm{e}$ and $7 \mathrm{~g}(\mathrm{MIC}=6.25 \mu \mathrm{g} / \mathrm{ml})$ were found to be more potent than Ampicillin $(\mathrm{MIC}=250 \mu \mathrm{g} / \mathrm{ml})$ against gram positive bacteria $B$. Subtilis Against $S$. aureus, compounds $\mathbf{6 d}, \mathbf{6 h}, \mathbf{7 a}, \mathbf{7 e}, \mathbf{7 g}$ and $7 \mathbf{i}(\mathrm{MIC}=100 \mu \mathrm{g} / \mathrm{ml})$ and against $B$. Subtilis compounds $\mathbf{6 c}, \mathbf{7 a}$ and $\mathbf{7 e}(\mathrm{MIC}=100 \mu \mathrm{g} / \mathrm{ml})$ demonstrated 
more inhibition than Ampicillin ( $\mathrm{MIC}=250 \mu \mathrm{g} / \mathrm{ml})$ and comparable activity to Norfloxacin $(\mathrm{MIC}=100 \mu \mathrm{g} / \mathrm{ml})$. Compounds $\mathbf{6 a}, \mathbf{6 c}, \mathbf{6 e}, \mathbf{6 g}$ and $\mathbf{7 f}(\mathrm{MIC}=125$ $\mu \mathrm{g} / \mathrm{ml}$ ) against $S$. aureus, while compounds $6 \mathbf{a}, 6 \mathbf{b}, 6 \mathbf{6}, 6 \mathbf{6}, 6 \mathbf{h}, 7 \mathbf{b}, 7 \mathbf{d}$ and $7 \mathbf{i}$ ( $\mathrm{MIC}=125 \mu \mathrm{g} / \mathrm{ml}$ ) against $B$. Subtilis displayed better activity as compare to Ampicillin $(\mathrm{MIC}=250 \mu \mathrm{g} / \mathrm{ml}$ ). Moderate inhibition were shown by compounds $\mathbf{6 b}, \mathbf{6 i}, \mathbf{7 c}$ and $\mathbf{7 d}(\mathrm{MIC}=200 \mu \mathrm{g} / \mathrm{ml})$ against $S$. aureus than Ampicillin $(\mathrm{MIC}=$ $250 \mu \mathrm{g} / \mathrm{ml}$ ). Similarly, compound $\mathbf{6 i}(\mathrm{MIC}=200 \mu \mathrm{g} / \mathrm{ml})$ displayed moderate activity against B.subtilis. Compound $\mathbf{6 f}(\mathrm{MIC}=250 \mu \mathrm{g} / \mathrm{ml})$ against $S$. aureus and compounds $\mathbf{7} \mathbf{c}, \mathbf{7 f}$ and $\mathbf{7 h}(\mathrm{MIC}=250 \mu \mathrm{g} / \mathrm{ml})$ against $B$. Subtilis showed comparable activity to Ampicillin (MIC $=250 \mu \mathrm{g} / \mathrm{ml}$ ).

In case of gram negative bacteria, compound $7 \mathbf{b}(\mathrm{MIC}=50 \mu \mathrm{g} / \mathrm{ml})$ was displayed outstanding inhibitory effect against $E$. Coli compare to Ampicillin $(\mathrm{MIC}=100 \mu \mathrm{g} / \mathrm{ml})$ and comparable activity to Chloramphenicol $(\mathrm{MIC}=50$ $\mu \mathrm{g} / \mathrm{ml})$. Against E. Coli, compounds $6 \mathbf{d}$ and $6 \mathbf{i}(\mathrm{MIC}=62.5 \mu \mathrm{g} / \mathrm{ml})$ depicted remarkable activity compare to Ampicillin ( $\mathrm{MIC}=100 \mu \mathrm{g} / \mathrm{ml}$ ). Compound $\mathbf{7 h}$ $(\mathrm{MIC}=100 \mu \mathrm{g} / \mathrm{ml})$ against $E$. Coli and compounds $\mathbf{6 c}, \mathbf{6 d}$ and $7 \mathbf{i}(\mathrm{MIC}=100 \mu \mathrm{g} /$ $\mathrm{ml}$ ) against $S$. Typhi were found to equipotant to Ampicillin (MIC $=100 \mu \mathrm{g} / \mathrm{ml}$ ). Antifungal assessment data of target compounds revealed that Compounds 7e, $7 \mathbf{h}(\mathrm{MIC}=100 \mu \mathrm{g} / \mathrm{ml})$ against $A$. Niger exhibited equal inhibition to Griseofulvin (MIC $=100 \mu \mathrm{g} / \mathrm{ml}$ ) and Nystatin (MIC $=100 \mu \mathrm{g} / \mathrm{ml}$ ). Compounds 6d, $7 \mathbf{b}(\mathrm{MIC}=100 \mu \mathrm{g} / \mathrm{ml})$ against $C$. Albicans exerted excellent inhibition compare to Griseofulvin ( $\mathrm{MIC}=500 \mu \mathrm{g} / \mathrm{ml}$ ) and equal potency to Nystatin $(\mathrm{MIC}=100 \mu \mathrm{g} / \mathrm{ml})$. Against C. Albicans, compounds $\mathbf{6 b}$ and $\mathbf{6 g}(\mathrm{MIC}=200$ $\mu \mathrm{g} / \mathrm{ml})$; compounds

6h, 7d and $7 \mathbf{i}(\mathrm{MIC}=250 \mu \mathrm{g} / \mathrm{ml})$ exhibited significant activity compare to Griseofulvin $(\mathrm{MIC}=500 \mu \mathrm{g} / \mathrm{ml})$

Table I. Antibacterial Activity MIC $(\mu \mathrm{g} / \mathrm{mL})$ of the compounds $6 \mathrm{a}-\mathrm{i}$ and $7 \mathrm{a}-\mathrm{i}$.

\begin{tabular}{|c|c|c|c|c|c|c|}
\hline \multirow{2}{*}{ Compounds } & \multicolumn{2}{|c|}{ Gram Positive Bacteria } & \multicolumn{2}{|c|}{ Gram Negative Bacteria } & \multicolumn{2}{|c|}{ Fungi } \\
\hline & $\begin{array}{l}\text { S.Aureus } \\
\text { MTCC96 }\end{array}$ & $\begin{array}{l}\text { B.Subtilis } \\
\text { MTCC441 }\end{array}$ & $\begin{array}{c}\text { E.Coli } \\
\text { MTCC443 }\end{array}$ & $\begin{array}{c}\text { S.Typhi } \\
\text { МТССС98 }\end{array}$ & $\begin{array}{c}\text { A.Niger } \\
\text { MTCC282 }\end{array}$ & $\begin{array}{l}\text { C.Albicans } \\
\text { MTCC227 }\end{array}$ \\
\hline $6 \mathbf{a}$ & 125 & 125 & 250 & 125 & 500 & $>1000$ \\
\hline $6 b$ & 200 & 125 & 200 & 200 & 250 & 200 \\
\hline $6 c$ & 125 & 100 & 125 & 100 & 500 & 500 \\
\hline 6d & 100 & 200 & 62.5 & 100 & 500 & 100 \\
\hline $6 e$ & 125 & 62.5 & 250 & 250 & $>1000$ & 500 \\
\hline 6f & 250 & 125 & 125 & 200 & $>1000$ & 500 \\
\hline $6 \mathrm{~g}$ & 125 & 125 & 250 & 125 & 250 & 200 \\
\hline $6 h$ & 100 & 125 & 200 & 200 & 500 & 250 \\
\hline $6 \mathbf{i}$ & 200 & 200 & 62.5 & 200 & 1000 & 200 \\
\hline $7 a$ & 100 & 100 & 250 & 250 & 500 & $>1000$ \\
\hline $7 b$ & 62.5 & 125 & 50 & 200 & 500 & 100 \\
\hline $7 c$ & 200 & 250 & 250 & 200 & $>1000$ & 500 \\
\hline $7 d$ & 200 & 125 & 250 & 250 & 500 & 250 \\
\hline $7 e$ & 100 & 100 & 200 & 200 & 100 & $>1000$ \\
\hline $7 f$ & 125 & 250 & 250 & 250 & 500 & 500 \\
\hline $7 g$ & 100 & 62.5 & 125 & 200 & 1000 & 1000 \\
\hline $7 \mathrm{~h}$ & 62.5 & 250 & 100 & 200 & 100 & 500 \\
\hline $7 \mathbf{i}$ & 100 & 125 & 200 & 100 & 250 & 250 \\
\hline Ampicillin & 250 & 250 & 100 & 100 & - & - \\
\hline Chloramphenicol & 50 & 50 & 50 & 50 & - & - \\
\hline Norfloxacin & 10 & 100 & 10 & 10 & - & - \\
\hline Griseofulvin & - & - & - & - & 100 & 500 \\
\hline Nystatin & - & - & - & - & 100 & 100 \\
\hline
\end{tabular}

Structure activity relationship established from the analysis of data reported in Table.1, lead to some general conclusions that mainly two structural features have influence on biological potential of synthesized compounds: 1) Substitution on phenyl ring. 2) Position of attachment of coumarin and pyridine moieties to each other. Observations indicate that the compounds $\mathbf{6 b}, \mathbf{6 e}, \mathbf{6 h}$, $\mathbf{7 b}, \mathbf{7 e}$ and $\mathbf{7 h}$ bearing weak electron releasing methyl group $\left(\mathrm{R}_{3}=\mathrm{CH}_{3}\right)$ showed outstanding activity compare to parent targets. The increased efficiency attributed to lipophilicity of methyl group. Introduction methoxyl group $\left(\mathrm{R}_{3}=\mathrm{OCH}_{3}\right)$ exerted reduced activity compare to parent analogs. It is interesting to note that compounds $\mathbf{7 a - i}$ possess promising antimicrobial activity against gram positive bacteria $B$. Subtilis and $S$. aureus, while compounds 6a-i demonstrate excellent activity against gram negative bacteria $E$. Coli and $S$. Typhi. We also noticed that among the compounds $6 \mathbf{6}-\mathbf{i}$ and $7 \mathbf{a}-\mathbf{i}$, compounds bearing 4-methyl-7-methoxycoumarin-8-yl moiety at $6^{\text {th }}$ position of pyridine ring, i.e. compounds $\mathbf{7 a - i}$ were more efficient compare to compounds $\mathbf{6 a - i}$.

\section{EXPERIMENTAL SECTION}

All the melting points were determined on $\mu$ Thermocal 10 apparatus. All the IR spectra ( $\mathrm{KBr}$ disc) were recorded on Shimadzu FT-IR 8400$\mathrm{S}$ spectrometer. ${ }^{1} \mathrm{H}-\mathrm{NMR}$ and ${ }^{13} \mathrm{C}-\mathrm{NMR}$ spectra were recorded on Bruker Avance 400 spectrometer operating at $400 \mathrm{MHz}$ for ${ }^{1} \mathrm{H}-\mathrm{NMR}$ and $100 \mathrm{MHz}$ for ${ }^{13} \mathrm{C}$-APT. The chemical shift $(\delta)$ is reported in ppm using chloroform-d as a solvent and calibrated standard solvent signal. Mass spectra were recorded on Shimadzu QP 2010 spectrometer. Elemental analysis was carried out on Perkin-Elmer $2400 \mathrm{C}-\mathrm{H}-\mathrm{N}-\mathrm{S}-\mathrm{O}$ Analyzer Series-II.

1-[2(H)-1-benzopyran-3-yl]-3-aryl-prop-2-en-1-ones (coumarinoyl Chalcone) 3a-f ${ }^{33}$, 4-methyl-3-phenyl-6-coumarinoyl methyl pyridinium bromide salt $4^{26}$ and 7-methoxy-4-methyl-8-coumarinoyl methyl pyridinium bromide salt $5^{27}$ were prepared according to literature procedure.

General procedure for the synthesis of 4-aryl-2-(coumarin-3-yl)-6-(4methyl-3-phenyl coumarin-6-yl)pyridines compounds 6a-i: 
A solution of 4-methyl-3-phenyl-6-coumarinoyl methyl pyridinium salt (4) $(0.003 \mathrm{~mol})$ in glacial acetic acid $(15 \mathrm{~mL})$ was charged in a round bottom flask. Ammonium acetate $(0.03 \mathrm{~mol})$ and an appropriate 1-[2(H)1-benzopyran-3-yl]-3-aryl-prop-2-en-1-ones (coumarinoyl Chalcone) 3a-f $(0.003 \mathrm{~mol})$ in glacial acetic acid $(15 \mathrm{~mL})$ were add to the solution in the flask with stirring. The reaction mixture was further stirred for 30 minutes and then refluxed for 8 hours. It was allowed to cool at room temperature. The reaction mixture was poured into ice-cold water and extracted with chloroform (3x $30 \mathrm{ml}$ ). The organic layer was then washed with water and then dried over anhydrous sodium sulfate. The removal of chloroform under reduced pressure gave gummy material which was subjected to column chromatography using silica gel and chloroform- petroleum ether (60-80) (9:1) as an eluent to give compounds 6a-i. The compounds were recrystallized from chloroform-hexane.

4-aryl-2-(coumarin-3-yl)-6-(4-methyl-3-phenyl coumarin-6-yl) pyridine (6a): White Solid, Yield $65 \%$; $\mathrm{mp} 282^{\circ} \mathrm{C}$; Anal. Calcd. for $\mathrm{C}_{36} \mathrm{H}_{23} \mathrm{NO}_{4}$ : C, 81.10; H, 4.38; N, 2.59\%. Found: C, 81.04; H, 4.34; N, 2.63\%; IR $\left(\mathrm{KBr}, v_{\max } \mathrm{cm}^{-1}\right)$ : 3054, 2924, 1716, 1611 and 1457 ; ${ }^{1} \mathrm{H}$ NMR $(400 \mathrm{MHz}$, $\left.\mathrm{CDCl}_{3}\right): \delta 2.47\left(3 \mathrm{H}, \mathrm{s}, \mathrm{CH}_{3}\right), 7.28-7.93(16 \mathrm{H}, \mathrm{m}, \mathrm{Ar}-\mathrm{H}), 8.35(1 \mathrm{H}, \mathrm{dd}, J=$ $8.8 \mathrm{~Hz}$ and $1.6 \mathrm{~Hz}, \mathrm{C}$ " $-\mathrm{H}), 8.42\left(1 \mathrm{H}\right.$, poorly resolved doublet, $\mathrm{C}$ "' $\left.{ }_{5}-\mathrm{H}\right), 8.68$ $\left(1 \mathrm{H}\right.$, poorly resolved doublet, $\left.\mathrm{C}_{3}-\mathrm{H}\right), 8.95\left(1 \mathrm{H}, \mathrm{s}, \mathrm{C}^{\prime}-\mathrm{H}\right) ;{ }^{13} \mathrm{C}$ APT $(100$ $\left.\mathrm{MHz}, \mathrm{CDCl}_{3}\right): \delta 16.8\left(\mathrm{CH}_{3}\right), 116.5(\mathrm{CH}), 117.3(\mathrm{CH}), 118.2(\mathrm{CH}), 119.5(\mathrm{C})$, $120.8(\mathrm{C}), 123.7(\mathrm{CH}), 124.7(\mathrm{CH}), 125.3(\mathrm{C}), 127.2(\mathrm{CH}), 127.3(\mathrm{CH}), 127.8(\mathrm{C})$, $128.4(\mathrm{CH}), \quad 128.5(\mathrm{CH}), \quad 128.9(\mathrm{CH}), \quad 129.2(\mathrm{CH}), 129.3(\mathrm{CH}), 130.1(\mathrm{CH})$, 130.2(CH), 132.3(CH), 134.4(C), 135.7(C), 138.4(C), 142.8(CH), 147.7(C), 150.5(C), 151.7(C), 153.4(C), 154.0(C), 156.0(C), 160.3(CO) and $160.7(\mathrm{CO})$.

General procedure for the synthesis of 4-aryl-2-(coumarin-3-yl)-6-(7methoxy-4-methyl coumarin-8-yl)pyridines 7a-i:

A solution of 4-methyl-7-methoxy-8-coumarinoyl methyl pyridinium salt (5) $(0.003 \mathrm{~mol})$ in glacial acetic acid $(15 \mathrm{~mL})$ was charged in a round bottom flask. Ammonium acetate $(0.03 \mathrm{~mol})$ and an appropriate 1-[2(H)-1-benzopyran3-yl]-3-aryl-prop-2-en-1-ones (coumarinoyl Chalcone) 3a-f $(0.003 \mathrm{~mol})$ in glacial acetic acid $(15 \mathrm{~mL})$ were add to the solution in the flask with stirring . The reaction mixture was further stirred for 30 minutes and then refluxed for 12 hours. It was allowed to cool at room temperature. The reaction mixture was poured into ice-cold water and extracted with chloroform (3x $30 \mathrm{ml})$. The organic layer was then washed with water and then dried over anhydrous sodium sulfate. The removal of chloroform under reduced pressure gave gummy material which was subjected to column chromatography using silica gel and chloroform-petroleum ether (80-20) as an eluent to give compounds 7a-i. The compounds were recrystallized from chloroform.

4-aryl-2-(coumarin-3-yl)-6-(4-methyl-7-methoxycoumarin-8-yl) pyridine (7a):

White solid, Yield $60 \%$; mp $280^{\circ} \mathrm{C}$; Anal. Calcd. for $\mathrm{C}_{31} \mathrm{H}_{21} \mathrm{NO}_{4}$ : C, 78.90 ; $\mathrm{H}, 4.42$; N, 3.01\%. Found: C, 78.97; H, 4.49; N, 2.97\%; IR $\left(\mathrm{KBr}, v_{\text {. }} \mathrm{cm}^{-1}\right)$ : $3057,2923,1724,1611$ and $1457 ;{ }^{1} \mathrm{H}$ NMR $\left(400 \mathrm{MHz}, \mathrm{CDCl}_{3}\right): \delta 2.69(3 \mathrm{H}$, $\left.\mathrm{s}, \mathrm{CH}_{3}\right), 3.90\left(3 \mathrm{H}, \mathrm{s}, \mathrm{OCH}_{3}\right), 6.21\left(1 \mathrm{H}, \mathrm{s}, \mathrm{C}_{3}{ }^{\prime \prime}-\mathrm{H}\right), 7.79-7.06(12 \mathrm{H}, \mathrm{m}, \mathrm{Ar}-\mathrm{H})$, $8.59\left(1 \mathrm{H}, \mathrm{d}, J=2 \mathrm{~Hz}, \mathrm{C}_{3}-\mathrm{H}\right), 8.76\left(1 \mathrm{H}, \mathrm{s}, \mathrm{C}_{4}^{\prime}-\mathrm{H}\right) ;{ }^{13} \mathrm{C}-\mathrm{APT}\left(100 \mathrm{MHz}, \mathrm{CDCl}_{3}\right): \delta$ $19.61\left(\mathrm{CH}_{3}\right), 56.47\left(\mathrm{OCH}_{3}\right), 108.33(\mathrm{CH}), 110.34(\mathrm{C}), 111.63(\mathrm{CH}), 112.23(\mathrm{CH})$, 114.31(C), 116.28(CH), 119.72(C), 121.36(CH), 124.09(CH), 124.50(CH), 126.22(CH), 127.46(CH), 129.04(CH), 129.19(CH), 131.98(CH), 138.30(C), $143.72(\mathrm{CH}), \quad 149.29(\mathrm{C}), \quad 150.81(\mathrm{C}), \quad 150.88(\mathrm{C}), 151.48(\mathrm{C}), 152.21(\mathrm{C})$, 153.99(C), 157.10(C), 159.18(C), 160.11(CO), 160.53(CO).

\section{Biological Assay}

All the synthesized compounds were screened for their antimicrobial activity against two Gram-positive bacteria viz. Bacillus subtilis (MTCC 441) and Staphylococcus aureus (MTCC 96), two Gram-negative bacteria viz. Escherichia coli (MTCC 443) and Salmonella typhi (MTCC 98) and two fungi viz. Aspergillus niger (MTCC 282) and Candida albicans (MTCC 227). All MTCC cultures were collected from Institute of Microbial Technology, Chandigarh and tested against above mentioned standard drugs. Mueller Hinton Broth was used as nutrient medium to grow and dilute the compound suspension for the test bacteria and Sabouraud Dextrose Broth was used for fungal nutrition. The size of the inoculum for the test strain was adjusted to $10^{8}$ colony forming unit (CFU) per milliliter by comparing the turbidity. In the present study, ampicillin and norfloxacin were used as standard antibacterial drugs, whereas nystatin and griseofulvin were used as standard antifungal drugs. DMSO was used as a diluent to get the desired concentration of compounds to test upon standard bacterial strains. Each synthesized compound and standard drugs were diluted obtaining $2000 \mu \mathrm{gmL}^{-1}$ concentration, as a stock solution. In primary screening 1000,500 and $250 \mu \mathrm{gmL}^{-1}$ concentrations of the synthesized drugs were taken. The active synthesized compounds found in this primary screening were further diluted to obtain $200,125,100,62.5,50,25,12.5$ and $6.250 \mu \mathrm{gmL}^{-1}$ concentrations for secondary screening to test in a second set of dilution against all microorganisms. The lowest concentration, which showed no visible growth (turbidity) after spot subculture was considered as MIC for each compound.

\section{CONCLUSION}

From present study, we summarized that employed synthetic strategy provide efficient route for the synthesis of asymmetrically substituted 4-aryl2,6-di(coumarinyl) pyridines by Krohnke's protocol in good yield. Moreover the starting precursors were also easy to prepare from synthesis point of view. Antimicrobial study on target compounds concluded that the all the compounds exerted promising activity against gram positive bacteria and gram negative. The target compounds showed feeble activity against fungal pathogens. The compounds $6 \mathbf{d}, 7 \mathbf{b}, 7 \mathrm{~g}$ and $7 \mathrm{~h}$ were most proficient members of the series.

Acknowledgements: The authors YLC, KNK and RRG are thankful to the Head, Department of Chemistry, Sardar Patel University for providing research facilities. Financial assistance to the authors from the University Grants Commission, New Delhi, India, is highly acknowledged.

\section{REFERENCES}

1. S. Sandhu, Y. Bansal, O. Silakari, G. Bansal, Bioorg. Med. Chem. 22, 3806, (2014)

2. S. Rosselli, A. Maggio, G. Bellone, C. Formisano, A. Basile, C. Cicala, A. Alfieri, N. Mascolo, M. Bruno, Planta. Med. 73, 116, (2007)

3. A. Kamal, S. F. Adil, J. R. Tamboli, B. Siddardha, U. S. N. Murthy, Lett. Drug. Des. Discov. 6, 201, (2009)

4. K. V. Sashidhara, M. Kumar, R. K. Modukuri, R. Sonkar, G. Bhatia, A. K. Khanna, S. Rai, R. Shukla, Bioorg. Med. Chem. Lett. 21, 4480, (2011)

5. K. V. Shashidhara, A. Kumar, M. Kumar, A. Srivastva, A. Puri, Bioorg. Med. Chem. Lett. 20, 6504, (2010)

6. M. Campos-Toimil, F. Orallo, L. Santana, E. Uriarte, Bioorg. Med. Chem. $12,783,(2002)$

7. R. B. Moffett, J. Med. Chem. 7, 446, (1964)

8. H. Osman, A. Arshad, C. K. Lam, M. C. Bagley, Chem. Cent. J. 6, 32, (2012)

9. A. Manvar, A. Malde, J. Verma, V. Virsodia, A. Mishra, K. Upadhyay, H. Acharya, E. Coutinho, A. Shah, Eur. J. Med. Chem. 43, 2395, (2008)

10. R. Argotte-Ramos, G. Ramírez-Avila, M. Rodríguez-Gutiérrez, M. OvillaMuñoz, H. Lanz-Mendoza, M. H. Rodríguez, M. González-Cortazar, L. Alvarez. J. Nat. Prod. 69, 1442, (2006)

11. R. B. Moffett, U. S. Patent, 3, 156, 697, (1964)

12. B. Sreenivasulu, V. Sundaramurthy, R. N. V. Subba, Proc. Ind. Acad. Sci., Sec. A. 79, 41, (1974)

13. R. B. Moffett, U. S. Patent, 3, 201, 406, (1965)

14. R. B. Moffett, J. Med. Chem. 7, 446, (1964)

15. D. I. Brahmbhatt, C. V. Patel, V. G. Bhila, N. H. Patel, A. A. Patel, Med. Chem. Res. 24 1596, (2015)

16. H. B. Lad, R. R. Giri, D. I. Brahmbhatt, Chin. Chem. Lett. 24, 227, (2013)

17. V. G. Bhila, C. V. Patel, N. H. Patel, D. I. Brahmbhatt, Med. Chem. Res. 22, 4338, (2013)

18. N. H. Patel, A. K. Patel, C. V. Patel, A. A. Patel, D. I. Brahmbhatt, Arkivoc ii, 283, (2010)

19. D. I. Brahmbhatt, J. M. Gajera, V. P. Pandya, M. P. Patel, Ind. J. Chem. $46 \mathrm{~B}, 869,(2007)$

20. D. I. Brahmbhatt, V. P. Pandya, C. N. Patel, M. A. Patel, Ind. J. Chem. 44B, 1863, (2005)

21. R. R. Giri, H. B. Lad, V. G. Bhila, C. V. Patel, D. I. Brahmbhatt, Synth. Commun. 45(3), 363, (2015)

22. H. B. Lad, R. R. Giri, Y. L. Chovatiya, D. I. Brahmbhatt, J. Serb. Chem. Soc. doi: $10.2298 / \mathrm{JSC} 140804004 \mathrm{~L}$

23. A. K. Patel, N. H. Patel, M. A. Patel, D. I. Brahmbhatt, Arkivoc xi, 28, (2010)

24. F. Krohnke, Synthesis, 1, 1, (1979)

25. NCCLS (National Committee for Clinical Laboratory Standards) (2002) 940, West Valley Road, Suite 1400, Wayne, Pennsylvania 19087-1898, USA. Performance Standards for Antimicrobial Susceptibility Testing; Twelfth Informational Supplement (ISBN 1-56238-454-6), M100-S12 (M7)

26. C. F. Koelsch, J. Am. Chem. Soc. 72, 2993, (1950)

27. D. I. Brahmbhatt, B. R. Hirani, Ind. J. Chem., Sect. B. 33, 1072, (1994) 